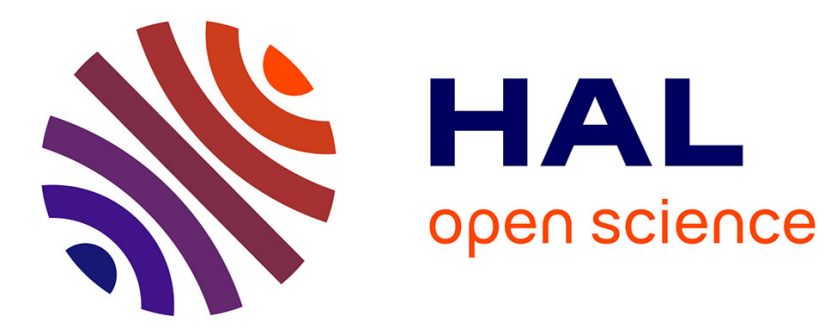

\title{
Locating adverbials in discourse
}

\author{
Laure Vieu, Myriam Bras, Nicholas Asher, Michel Aurnague
}

\section{To cite this version:}

Laure Vieu, Myriam Bras, Nicholas Asher, Michel Aurnague. Locating adverbials in discourse. Journal of French Language Studies, 2005, 15 (2), pp.173-193. 10.1017/S0959269505002073 . hal-00671743

\section{HAL Id: hal-00671743 \\ https://hal.science/hal-00671743}

Submitted on 18 Feb 2012

HAL is a multi-disciplinary open access archive for the deposit and dissemination of scientific research documents, whether they are published or not. The documents may come from teaching and research institutions in France or abroad, or from public or private research centers.
L'archive ouverte pluridisciplinaire HAL, est destinée au dépôt et à la diffusion de documents scientifiques de niveau recherche, publiés ou non, émanant des établissements d'enseignement et de recherche français ou étrangers, des laboratoires publics ou privés. 


\title{
Locating Adverbials in Discourse
}

\author{
Laure Vieu (IRIT-CNRS Toulouse and LOA-ISTC-CNR Trento) \\ Myriam Bras (ERSS-CNRS and Université Toulouse-Le Mirail) \\ Nicholas Asher (University of Texas at Austin) \\ Michel Aurnague (IKER-CNRS Bayonne)
}

\section{Introduction}

This paper offers an analysis of the discursive role of Locating Adverbials (henceforth LA). LAs are prepositional phrases that locate the eventualities in time and/or in space, such as un peu plus tard, ce matin, deux kilomètres plus loin, près de l'arbre ('a little later', 'this morning', 'two kilometres further', 'near the tree').

In Aurnague et al. (2001), we gave a compositional semantics for these adverbials together with their syntactic analysis. Following Maienborn (1995), we considered two syntactic positions for LAs, namely VP Adjunct position (Verb Phrase modifier) and IP Adjunct position (Sentence modifier). As a matter of fact, LAs cannot be categorized as VP-Adj or IPAdj once and for all. They do not fulfil the classical tests for distinguishing 
between the two categories, for example those of Molinier and Lévrier (2000) for French, or those of McKercher (1996) for English, as they prove to have both types of properties for different occasions of use. For us, these two positions classify the occurrences of LAs, but not LAs themselves.

We assumed that, when they are in VP-Adj position, these adverbials mainly contribute to the semantic content of the sentence, and that this position corresponds to the standard use of LAs. On the other hand, we described the role of IP-Adj LAs as modifying the truth conditions of the whole proposition, i.e. saying when or where it is true.

In this paper, we focus on the latter case, that of IP-Adj locating adverbials, i.e. sentential adverbials. We limit this study to cases where they are dislocated to the left of the main IP structure of the sentence, and we assume that they are all IP Adjuncts cases, following McConnell-Ginet (1982), Johnston (1994), Maienborn (1995), De Swart (1999). ${ }^{1}$

When left dislocated, LAs play an important part in structuring discourse, although they are not considered as discourse connectives (see Borillo et al., 2004; and Charolles et al., this volume). It is precisely this discursive contribution of LAs that we want to tackle here, providing both a descriptive and formal account of this contribution. We will use the framework of

${ }^{1}$ As the initial vs final position is not always a decisive criterion to distinguish between the two positions and the associated functions, we used a test (in Aurnague et al., 2001: 16) that assumes that IP-Adj cannot fall under the scope of negation, while VP-Adj can (see also Johnston, 1994: 141; and De Swart, 1999: 339). 
Segmented Discourse Representation Theory (SDRT), a logical theory of the semantics-pragmatics interface (Asher, 1993; Asher and Lascarides, 2003) to develop our formal analysis.

In previous work (Asher et al., 1995), we showed that the temporal and spatial LAs can receive a spatio-temporal interpretation, provided they appear within a trajectory description. We will account for these particular interpretations within the general framework that will have been set up for the IP adjunct LAs.

We will first recall what is the semantic contribution of LAs as VP-Adj at the sentence level in Section 1. Then we will describe the behaviour of LAs as IP-Adj and their impact on discourse structure in Section 2. In Section 3, we will formalize this description in SDRT. Lastly, our account on spatiotemporal interpretations will be given in Section 4.

\section{Semantic contribution of locating adverbials as VP-Adj}

Let us first recall that, when they are in VP Adjunct position, LAs play a well-understood role at the sentence level: they locate the eventuality described by the rest of the sentence, in space (1) or in time (2).

(1) Marie mange des abricots dans le jardin.

(2) Marie a acheté des abricots ce matin.

In Aurnague et al. (2001), we gave the compositional semantics of these adverbials together with their syntactic analysis. These adverbials are all 
Prepositional Phrases with possibly empty positions, including nouns whose lexical semantics bears a temporal or spatial feature. We will present some examples of both descriptions in this section $(§ 1.2)$. Then we will show how the PP combines with the VP at the sentence compositional semantics level (§1.3). Before that, we will briefly point out an important feature of our approach $(\S 1.1)$.

\subsection{Relational semantics}

In Aurnague et al. (2001), we defended a relational approach against the most widespread referential approaches. In such an analysis, the PP-LA does not introduce any new referent on top of that of its complement, but rather indicates that the eventuality and the LA complement have to stand in the relation denoted by the preposition. For example in (3), the preposition après 'after' only compels the joining event to be later than the meeting, whereas in a referential view, the whole LA would introduce a new temporal referent representing an interval described by après la reunion 'after the meeting'. In (4), the adverbial plus tard 'later' compels the falling asleep event to be located after a temporal referent provided by the context, and the DP deux heures 'two hours' gives the extension of the distance between the two temporal referents.

(3) Marie rejoignit Luc après la réunion.

(4) Marie s'endormit deux heures plus tard. 
We cannot lay out again here all the advantages of a relational semantics (see Aurnague et al., 2001), but we will pay particular attention in this paper to LAs like après la réunion or deux heures plus tard when they are in IPAdjunct position, as in (5):

(5) Après la réunion, Marie rejoignit Luc.

\subsection{Compositional semantics of LAs}

The internal syntactic structure of the LAs we studied in Aurnague et al. (2001) is that of a complex Prepositional Phrase with possibly empty positions as sketched in Fig. 1.

[insert Fig 1 about here]

In order to illustrate the way the semantics of a LA of the PP category is calculated in a compositional bottom-up fashion, we have labelled, on Fig. 2, the syntactic tree of deux jours après Noël 'two days after Christmas' with the semantic representation of each node. In the composition process, the semantics of the P' node applies to the semantics of the DP in SPEC position.

[insert Fig 2 about here]

The same kind of composition yields for à huit heures 'at eight o'clock' the following semantic representation:

$$
\begin{aligned}
& \lambda \mathrm{P} \lambda \mathrm{e} \exists \mathrm{y}^{\mathrm{T}} \exists \mathrm{v}^{\mathrm{T}}(\mathrm{P}(\mathrm{e}) \wedge \operatorname{Day}(\mathrm{v}) \wedge \mathrm{v}=? \wedge \operatorname{Hour}(\mathrm{y}) \wedge \mathrm{y} \subset \mathrm{v} \wedge \\
& \text { Calendar } \left.\left(\mathrm{y}^{\prime}, 8 \mathrm{~h}^{\prime}\right) \wedge \mathrm{e} \subseteq \mathrm{y}\right)
\end{aligned}
$$


The formula above includes an underspecified condition $v=$ ? to be resolved at the discourse semantics level, i.e. when the discourse context will be available, in the way described in Section 2.2.

More generally, the semantic representation of a LA is a formula like the following:

$(\mathrm{LA}-\mathrm{VP}) \quad \lambda \mathrm{P} \lambda \mathrm{e}(\mathrm{P}(\mathrm{e}) \wedge \phi(\mathrm{e}))$

where $\phi(e)$ is the LA contribution, $e$ is a variable to be bound by an eventuality $^{2}$ variable $^{3}$ introduced and quantificationally bound by the I node, and $P$ is the predicate given by the VP node.

\subsection{Compositional semantics at the sentence level}

The labelled tree in Fig. 3 shows how the VP-Adj LA's semantic representation described above combines with the rest of the sentence to yield the DRS representing the sentence semantic content for the example:

(6) Paul arriva à huit heures.

This representation is a Discourse Representation Structure (Kamp and Reyle, 1993), for which we adopt here a linear notation of DRSs: [U $\mid C]$. We will explain in Section 2.2 below how this DRS will be integrated in the representation of the whole discourse.

[insert Fig 3 hereabouts]

\footnotetext{
${ }^{2}$ Following the DRT tradition, we assume that eventualities are reified (Davidson, 1967) and can be of two types: events and states, (Kamp, 1981; Kamp and Reyle, 1993).

3 or an individual constant when the LA is an N' adjunct, e.g. le jour avant la réunion 'the day before the meeting' (see Aurnague et al., 2001: 18).
} 


\section{Semantic contribution of locating adverbials as IP-Adj}

In this section, we focus on the cases when the LA is in IP-Adj position and thus acts as a sentence modifier, as in (5) for example, whose syntactic tree is sketched in Fig. 4.

[insert Fig 4 here]

Let us recall that we consider that, following Johnston (1994: 28), the alternation between VP-Adj and IP-Adj positions does not correspond to two different senses of the LA. Therefore, and since the VP-Adj is taken to be the standard use of the LA, we assume when it is in IP-Adj position, the LA has basically the same semantic content and is represented by the same formula. As a consequence, in the IP-Adj case, the LA semantics also in principle follows the general scheme:

$$
(\mathrm{LA}-\mathrm{VP}) \quad \lambda \mathrm{P} \lambda \mathrm{e}(\mathrm{P}(\mathrm{e}) \wedge \phi(\mathrm{e}))
$$

but this time, there are no constants available to be combined with $\lambda P$ and $\lambda e$, as the IP node represents a full sentence whose semantics is a proposition.

We will show how to solve this problem in Section 3. First, we need to have a closer look at the linguistic behaviour of the LA in IP-Adj position. This descriptive study is the purpose of the present section. 


\subsection{IP-Adj LAs as Frame Introducers}

Classically, sentence modifiers are separated into two groups. Some sentence modifiers bear on facts, for example modal sentential adverbs (probably, certainly) that qualify the truth value of the sentence, and evaluative adverbs (unfortunately) that qualify the attitude of the speaker towards the sentence semantic content. Others bear on speech acts like frankly, honestly (Bonami et al., 2004).

LAs in IP-Adj position behave like modal adverbs, as they describe the temporal and/or spatial conditions in which the sentence semantics is to be evaluated:

(7) Hier, Marie est allée au marché.

But this semantic role at the sentential level is not the whole story. LAs in IP-Adj position have a semantic effect beyond the sentence in which they occur:

(8) Hier, Marie est allée au marché pour acheter des abricots.

Elle a fait une tarte délicieuse et nous nous sommes tous régalés.

The role of hier 'yesterday' in (8) is to introduce a temporal setting in which not only the first clause, but all the others are evaluated. Along the lines of the 'discourse framing hypothesis' of Charolles (1997), this temporal setting together with the set of clauses being grouped on the basis of this common evaluation criterion is called a 'discourse frame'. Here more precisely, we have a temporal discourse frame, as represented in Fig. 5. In (8), hier plays 
the role of a 'frame introducer'. This discursive phenomenon of framing is also called 'indexing': each clause in the frame is temporally indexed by the temporal information brought by the frame introducer. Indexing is a forward-looking process. The frame provides instructions for the interpretation of forthcoming text, as opposed to the backward-looking process of connection, where the connector introduces a relation to some element in the previous text.

[insert Fig.5 here]

Starting from the analysis of temporal framing in Le Draoulec and PéryWoodley (2003), we now turn to the question of how to analyze formally within SDRT the frame introducer role of IP-Adj LAs.

\subsection{Frame Introducers and Discourse Topics}

Frames can thus been seen as a kind of discourse segment, marked by the presence of an IP-Adj LA in their first sentence. Segmented Discourse Representation Theory (SDRT, as in Asher, 1993; Lascarides and Asher, 1993; Asher and Lascarides, 2003) is a theoretical tool for the analysis of discourse, which addresses in depth the complex interplay between the semantic contribution of sentences and their components and the segmentation of discourse. SDRT is therefore particularly suited to give a formal account of both the semantic contribution of the LA in IP-Adj position and the notion of discourse frame, and to explain their relationship. 
Analysing a discourse in SDRT amounts to building in an incremental way, from the logical formulas representing the semantics of each sentence (obtained by standard compositional semantics), a 'segmented discourse representation structure' or SDRS for the whole discourse. An SDRS is recursively defined as a set of speech-act labels, $\pi_{1}, \ldots \pi_{\mathrm{n}}$, related by discourse relations such that each speech-act label is associated with a 'discourse constituent', which is either simple - the logical formula representing a simple clause - or complex —an SDRS representing a discourse segment. Discourse relations are either 'coordinating', indicating a continuation of some discourse pattern, e.g., with a 'Narration', or 'subordinating', indicating a rupture, e.g., through an 'Elaboration' or an 'Explanation', and thus induce a hierarchical structure. SDRSs are built using the 'glue logic' that exploits various pragmatic principles (including Gricean principles) in a non-monotonic reasoning framework to recover the discourse relations that link the segments in any coherent discourse. In the remainder, we will assume the fundamentals of SDRT are known; for a detailed presentation of SDRT, see Asher and Lascarides (2003) and Busquets et al. (2001) for an introduction.

SDRT makes use of the notion of 'discourse topic' ${ }^{4}$ to account for some aspects of discourse coherence. In narratives, a genre in which topics play

\footnotetext{
${ }^{4}$ Discourse topics differ from so called sentence topics (or themes, or grounds) in theories of information structure, (see Vallduví, 1992 for example). We cannot examine in details here how the topic/focus information partition interacts with discourse topics, (see Txurruka, 1999, 2001), but it is worth mentioning that the contrast we draw between VP-
} 
an important role, it can be shown that temporal order does not suffice to organize a discourse: a discourse segment is coherent only if its subsegments share some common 'topic' (Asher, 2004). A discourse topic summarizes the semantic contents of the whole segment. For instance, in (9), the first sentence describes the explicit topic of the whole discourse:

(9) L'été de cette année là vit plusieurs changements dans la vie de nos héros $(\pi 1)$. François épousa Adèle $(\pi 2)$. Jean-Louis partit pour le Brésil $(\pi 3)$ et Paul s'acheta une maison à la campagne $(\pi 4)$. (Kamp and Rohrer, 1983: 261)

The explicit topic is a simple constituent $\pi l$, which is elaborated by the complex segment grouping the rest of the discourse, as can be seen on the schematized structure of the SDRS for (9) in Fig. 6.

[Fig 6 here]

We can slightly modify this example to make in (10) the same common topic implicit, as it is often the case:

(10) Cet été-là, François épousa Adèle $(\pi 1)$. Jean-Louis partit pour le Brésil $(\pi 2)$ et Paul s'acheta une maison à la campagne $(\pi 3)$.

In this case, the common topic $\pi$ is built by a generalization operator from the semantic contents of the clauses in the segment (Asher, 1993),

\footnotetext{
Adj and IP-Adj positions is translated in De Swart (1999) as a contrast in terms of information partition: IP-Adj are topics, VP-Adj can be focus or topics according to the structure of the proposition. De Swart's analysis is not incompatible with ours, although it stays at the sentence level, and presents some technical divergences.
} 
recovering ${ }^{5}$ roughly the same semantic contents as that of $\pi l$ in (9) and resulting in the same discourse structure as can be seen in Fig. 7.

[Fig7 here]

One may notice at this point that the LA in the first sentence, a frame introducer, plays an important role in the coherence of the discourse. Without it, $\left(10^{\prime}\right)$ is much more awkward as the common, implicit, topic is more difficult to recover:

(10') François épousa Adèle. Jean-Louis partit pour le Brésil et Paul s'acheta une maison à la campagne.

This observation leads us to hold that LAs in IP-Adj position significantly interact with discourse topics. In fact, we propose here to reinterpret the role of 'frame introducer' as that of 'new topic introducer' in the SDRT framework. In some sense, this means that the role of an LA in IP-Adj position is to announce 'I'm going to describe you some (possibly complex) event, yet to be specified, which is located so'. The observation of an extended example confirms this role. Every occurrence of the LAs in IP-Adj position in (11) corresponds to a change in topic, even when this change is not typographically marked by a paragraph change:

$$
\text { Eglises et Résistance }{ }^{6}
$$

\footnotetext{
${ }^{5}$ Let us recall that topics in SDRT are built incrementally. With the standard topic building procedure in SDRT, the first representation of $\pi$ 's content includes an eventuality which is a summary of $\pi 1$ and $\pi 2$, then this constituent is updated with the treatment of $\pi 3$, eventually yielding the one we have in Fig. 7. Taking into account the meaning of the LA, this procedure will here be changed, as will become clear in Section 3.
} 
[...] Mais lorsque la Gestapo démantela ce réseau de résistance en 1943, Bonhoeffer fut arrêté et déporté en camp de concentration. Il fut pendu le 9 avril 1945.

En 1932 [In 1932] se forma un groupe protestant national-socialiste, les 'Chrétiens allemands', qui réclamèrent après l'arrivée au pouvoir de Hitler la formation d'une Église du Reich, structurée selon le 'Führerprinzip' et rejetant les juifs, ce qui se réalisa quelques mois plus tard. L'Église protestante, désormais dirigée par les 'Chrétiens allemands', était devenue un instrument entre les mains de Hitler. En septembre 1933 [In September 1933] fut organisé le 'synode brun'; la majorité des responsables ecclésiastiques s'y rendirent en uniforme nazi. Il fut décidé, malgré l'opposition des adversaires des 'Chrétiens allemands', que les pasteurs qui n'étaient pas aryens seraient exclus de l'Église du Reich ; 70 responsables ecclésiastiques suivirent l'exemple du pasteur Koch et quittèrent alors la salle en signe de protestation.

Quelques semaines plus tard [Some weeks later], le pasteur Martin Niemöller appela les pasteurs hostiles à ces mesures antisémites à s'unir au sein d'une nouvelle organisation, le 'Pfarrernotbund', la 'Ligue d'urgence des pasteurs', qui respecterait les principes de

\footnotetext{
${ }^{6}$ This and some of the following examples are drawn from a corpus of texts describing the German resistance during WWII gathered from history textbooks by Delphine Bris and Jean-Marc Dubois from the Université de Haute Bretagne. We wish to thank Anne Le Draoulec and Marie-Paule Péry-Woodley for giving us access to this corpus.
} 
tolérance énoncés par la Bible et la profession de foi réformatrice. $[\ldots]$

In (11), en 1932 marks a 'discourse pop', i.e., the elaboration of the story of the previous resistance network is closed off, and a new sub-topic of the main topic of the whole text is introduced, the setting-up of the group 'the German Christians'. Similarly, en septembre 1933 also introduces a new topic, the 'brown synod', which may be linked to the previous one by a narration relation, thus marking a discourse pop. At the beginning of the last paragraph, quelques semaines plus tard closes the story of the brown synod and marks another discourse pop with the introduction of the new topic of the setting-up of the organization 'Pfarrernotbund'.

What is clear from such observations, is that in the IP-Adj position, LAs play a prominent role at the discourse structure level, and this is not limited to the fact that the localization extends over the sentence. The role of topic introducer is at least as important as the localization itself. Of course, localization still occurs, and it generally distributes over the constituents of the segment dominated by the topic, as observed in studies on discourse frames described above. However, as shown by Le Draoulec and PéryWoodley (2003), the boundaries of a frame, when considered only in its localization dimension, can be 'fuzzy', while the boundaries of a discourse segment under a given topic are always clear. This is illustrated again in example (11) by the fact that even if the whole paragraph elaborates the 
topic of the formation of the German Christians group, not all eventualities described there are actually located in 1932. In fact, Hitler's coming to power happened in 1933, therefore the creation of the Church of the Reich did not occur in 1932. In many cases, localization is fuzzy as the discourse does not mark explicitly whether a given eventuality, although clearly in the segment dominated by the topic introduced by the LA, is located or not by the LA. Let us recall what Le Draoulec and Péry-Woodley (2003: 138-139) themselves write about this phenomenon, comparing two segments elaborating the same topic, Hitler's putsch and its consequences, which are: reports of the same episode from separate sources (similar in terms of chronological organisation). ${ }^{7}$ They all turn out to exhibit the same kind of fuzziness, as illustrated in (12) and (13): ${ }^{8}$

(12) Le 8 novembre 1933 [On the $8^{\text {th }}$ of November 1933], ([...]), Hitler tente un coup de force, mais le putsch, mal organisé, échoue lamentablement : seize nazis sont tués par la police munichoise, et Hitler lui-même est arrêté. Lors du procès qui s'ensuit, le chef du parti nazi n'en réussit pas moins à se présenter comme un patriote révolté par les agissements d'une république indigne, [...]. Condamné en février 1924 à cinq ans d'emprisonnement, Hitler est libéré dès le mois de

7 Yahoo! Encyclopédie-Adolphe Hitler (http://fr.encyclopedia.yahoo.com/articles/ni/ ni_2367_p0.html) for (5); L'Allemagne nazie (course material) (http://perso.club-internet.fr/ erra/GVIDAL/nazisme.html) for (6).

${ }^{8}$ We have changed the original example numbering. 
décembre. Il a consacré ces quelques mois passés dans la forteresse de Landsberg à rédiger Mein Kampf (Mon combat), $[\ldots]$

(13) En 1923 [In 1923], [...] Hitler décide de profiter de la situation pour s'emparer du pouvoir par la force : [...]. C'est un échec qui fait 19 morts car la police de Munich ouvre le feu sur les Nazis. Hitler est condamné (seulement) à 9 mois de prison. Il en profite pour écrire un livre, Mein Kampf, qui précise sa doctrine. [...]

Example (12) leaves unclear whether the failure of the putsch is still bound to November $8^{\text {th }}$. In (13), the temporal scale has changed from day to year, and it is now the temporal location of the writing of Mein $\operatorname{Kampf}$ which is unspecified.

Similarly, in example (14) it can be seen that the segment with topic 'the breaking up of the "Communauté pour la paix et le renouveau" introduced by the LA en octobre 1944, actually localizes only the arrest of Hans Winkler and Werner Scharff in October 1944. The breaking up itself lasts longer, since Eugen Herman-Friede's arrest is explicitly located in December.

(14) 'Communauté pour la paix et le renouveau'

Hans Winkler, Günther Samuel et Erich Schwarz fondèrent après le pogrom de 1938 un cercle de discussion hostile au régime, qui se 
faisait passer pour un groupe d'épargne ('Sparverein Hoher Einsatz').

$[\ldots]$

En octobre 1944 [In October 1944], la Gestapo démantela ce réseau et arrêta Hans Winkler et Werner Scharff. Ce dernier fut assassiné le 16 mars 1945 dans le camp de concentration de Sachsenhausen, quelques semaines avant la libération du camp. Eugen HermanFriede, qui avait pris part aux activités de la 'Communauté pour la paix et le renouveau', fut arrêté le 11 décembre 1944 mais parvint à survivre à sa détention. La plupart des membres de ce groupe de résistance purent survivre grâce à la confusion qui régnait en Allemagne lors des derniers mois de la guerre.

We conclude that an LA in IP-Adj position actually locates only by default the various eventualities described by the sentences of the segment dominated by the topic introduced by the LA. We will now see how the meaning of LAs in IP-Adj position can be formally accounted for in SDRT.

\section{IP-Adjunct Locating Adverbials in SDRT}

\subsection{From compositional semantics to discourse structure}

As already mentioned in Section 1, we assume that locating adverbials that occur in IP-Adj or VP-Adj position have fundamentally the same semantics. But their position in the syntactic tree may invoke certain special operations 
that change their meaning. In fact, we have just seen that LA adverbials serve a particular discourse function when they are in an IP-Adj position.

This discourse function transforms the basic meaning of the adverbial in (LA-VP) reported below, where the adverb is a function from properties of eventualities into a property of an eventuality, ${ }^{9}$

$(\mathrm{LA}-\mathrm{VP}) \quad \lambda \mathrm{P} \lambda \mathrm{e}(\phi(\mathrm{e}) \wedge \mathrm{P}(\mathrm{e}))$

into a property of speech acts in (LA-IP). This property is one that furnishes an underspecified topic for its argument but serves to locate, spatially or temporally, the main eventuality introduced within the propositional content of that speech act. This transformation requires the addition of certain information to the basic meaning of the adverb and an operation of existential closure for the $\lambda$-abstracted variables. Existential closure (Diesing, 1992) turns our adverbial property into a proposition (LA-IP1) that can be the content of a speech act (LA-IP2):

$$
\begin{array}{ll}
(\text { LA-IP1 }) & \exists \mathrm{P} \exists \mathrm{e}(\phi(\mathrm{e}) \wedge \mathrm{P}(\mathrm{e})) \\
(\text { LA-IP2 }) & \exists \pi^{\prime} \pi^{\prime}:[\exists \mathrm{P} \exists \mathrm{e}(\phi(\mathrm{e}) \wedge \mathrm{P}(\mathrm{e}))]
\end{array}
$$

And taking into account the discourse function of this proposition which is to serve as a frame or topic for another speech act, the one in the IP to which it is adjoined, we have:

\footnotetext{
${ }^{9}$ This basic meaning is for VP-adjunct. Note that the same formula can be used also for an $\mathrm{N}$-adjunct, in which case the argument e is no longer necessarily an eventuality (Aurnague et al., 2001: 18).
} 
(LA-IP) $\quad \lambda \pi \exists \pi^{\prime}\left(\pi^{\prime}:[\exists \mathrm{P} \exists \mathrm{e}(\mathrm{P}(\mathrm{e}) \wedge \pi \nabla \mathrm{P})] \wedge \phi^{\text {Distr }}\left(\pi^{\prime}\right) \wedge\right.$ Elaboration $\left(\pi^{\prime}, \pi\right)$ )

where the variable $\pi$ is to be filled by the speech act introduced by the IP.

There are two new notational conventions in (LA-IP) that require comment. The first concerns the symbol $\nabla$, which expresses the relation that the argument on its left must have its content subsumed by the content of the term on its right. This ensures that $\pi^{\prime}$ acts like a topic to $\pi$, but because we do not at this point know what $\pi$ is, we cannot say exactly what the topic's content is. $\pi \nabla P$ specifies a constraint on the content of $\pi^{\prime}$ so that it will behave as a topic should. We capture with this underspecification the 'forward-looking' character of LAs in IP-adjunct position. As discourse proceeds the nature of $\pi$ may change. It may start out as a simple constituent but then evolve into a complex constituent if new attachments are made to the initial constituent modified by the adverbial. The update of the SDRS with the following sentences may also require an update of the topic $\pi^{\prime}$, as is usually done with constructed implicit topics.

The second is a modification of the property $\phi$ such that instead of simply holding on $e$, the main eventuality of the topic, the property distributes across the eventualities of all the constituents that elaborate the topic:

$$
\begin{aligned}
& \text { (DefDistr) } \quad \phi^{\text {Distr }}(\pi)=_{\text {def }} \forall \mathrm{e}\left(\exists \pi^{\prime} \quad \text { (Elaboration }\left(\pi, \pi^{\prime}\right) \wedge\right. \text { Main- } \\
& \text { eventuality } \left.\left.\left(e, K_{\pi^{\prime}}\right)\right)>\phi(e)\right)
\end{aligned}
$$


In effect we take $\phi^{\text {Distr }}\left(\pi^{\prime}\right)$ to be a constraint on the discourse structure subordinate to $\pi$. This ensures that all the constituents of the frame, i.e., the constituents $\pi_{i}$ elaborating the topic $\pi^{\prime}$ are located by the adverbial, i.e., this corresponds to the indexing of the frame in Charolles's terms (1997). For a number of adverbials, namely inclusive ones like dans le jardin 'in the garden' or lundi 'on Monday' and pure order ones like avant les vacances 'before the holidays' or devant la maison 'in front of the house', this could simply be inferred from the simpler $\phi(e)$ and Elaboration $\left(\pi^{\prime}, \pi_{i}\right)$, which has as a semantic consequence that the main eventuality of $\pi_{i}$ must be a spatiotemporal part of the main eventuality in $\pi^{\prime}, e . \phi^{\text {Distr }}$ is needed because there are many other adverbials for which the inference does not get through, for instance those involving a contact relation, as with sur la table 'on the table' and depuis la semaine dernière 'since last week', or those involving a distance, as with dix ans plus tard 'ten years later' and vingt mètres en face de la maison 'twenty metres in front of the house'.

Moreover, since the distribution is a default one (use of the non-monotonic implication >), the 'fuzziness' of the indexation described in the previous section is allowed. Additional information, e.g., an LA in VP-Adj position in some constituent, can block the inference for a particular event in the elaboration.

This property in (LA-IP) now needs to combine with the main IP. The IP's contribution, however, is not of the right form; it is just a propositional 
content and it needs to yield a speech act. We hypothesize that this operation is performed at some point in the syntactic tree and we will suppose that it can be triggered by the IP or higher adjoined LA. So the IP standardly yields a proposition $\psi$ and we will type-shift that into a speech act introducing 'determiner', using the Partee-Rooth (Partee and Rooth, 1983) type shifting operation:

$$
\text { (IP1) } \lambda \mathrm{P} \exists \pi(\pi:[\psi] \wedge \mathrm{P}(\pi))
$$

Standard lambda conversion of the discourse content of the LA in (LA-IP) with the type-shifted meaning of the main IP in (IP1) yields us:

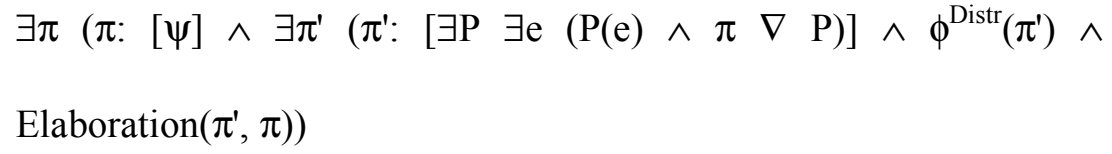

Let us see now how our proposal unfolds on the simple example (10), altering slightly the standard analysis and topic construction seen in Section 2. The analysis of the first sentence $\pi$, which starts with an LA in IP-Adj position and thus introduces two constituents, yields the SDRS represented on Fig. 8.1. The second sentence $\pi 2$ is then attached to $\pi l$ by a Continuation relation, a complex segment composed of $\pi 1$ and $\pi 2$ that elaborates the topic $\pi$ is introduced, and the topic is updated to summarize both $\pi l$ and $\pi 2$. When the third sentence which continues the elaboration is treated, it is added to the complex constituent and the topic is again updated. The resulting SDRS is shown on Fig. 8.2.

[insert Fig. 8.1. and 8.2. hereabouts] 
Before examining how our proposal behaves in some special cases, we would like to point out that semantic properties at the sentence level are correctly accounted for. Classical analyses of temporal LAs contrasting their VP-Adj and IP-Adj positions have focused on scope interactions with negation and quantificational adverbs (e.g., always) within the sentence (Johnston, 1994; De Swart, 1999). The introduction of two constituents, one with a discourse topic and the LA contribution and one with the IP contents, accounts for scope phenomena in a straightforward way. It allows the negation operator to apply on the IP constituent or the quantificational adverb to introduce the appropriate conditional structure over that constituent, all remaining within the segment elaborating the topic, i.e., under the scope of the LA.

\subsection{Spatial LAs}

The examples we have considered in Section 2 and here all involve temporal LAs. In fact, narratives are often structured in successive temporal episodes. But some narratives can be similarly structured with spatial LAs, as with à Kotéré and à Médine in example (15), and our analysis equally applies in this case.

(15) A Kotéré (Kaméra) [At Kotéré], un incident imprévu faillit mettre fin à notre voyage avant qu'il fût commencé.

Mes hommes, en arrivant, trouvant le chemin barré par la porte d'un lougan (champ, jardin), voulurent la faire sauter. Une vieille femme 
qui s'y opposa fut bousculée, et avant que j'eusse pu rétablir l'ordre, le village, en entier, sortait aux cris de la femme et assaillait nos hommes à coups de bâton, leur arrachant leurs fusils. [...]

Le seul résultat de cette affaire fut le verre du chronomètre cassé dans ma poche, $[\ldots]$.

A Médine [At Medina], je m'occupai de la dernière installation de mes bagages, je pris des vivres, je disposai les charges des animaux, je fis emplette de quelques articles oubliés à Saint-Louis, et laissant M. Quintin chargé de préparer ces derniers détails, je me livrai à l'exploration du fleuve au-dessus des chutes du Felou au moyen du canot que j'avais apporté.

[E. Mage, Relation d'un voyage d'exploration au Soudan (18631866), Revue Maritime et Coloniale, 1867, XX (mai), pp. 26-88.]

One may also notice in (15), in the segment starting with the LA à Médine, that the fuzziness of the spatial location is also present: all the luggage organization and the shopping clearly happen at Medina, while the river exploration 'above the Felou waterfalls' probably does not occur strictly speaking at Medina. Nevertheless, the whole paragraph is clearly an elaboration of a topic like 'the stay of our group at Medina'.

\subsection{The imparfait: A special problem?}

All examples above consider LAs in IP-Adj position in sentences in which the main eventuality is an event, usually in passé simple. Let us examine 
now whether our proposal applies also when the main eventuality is a state, as when using an imparfait.

In the minimalist semantics of SDRT, tenses like the simple past or the future only introduce conditions of anteriority or futurity on the main eventuality. In SDRT as in DRT, we then characterize the main eventuality as bounded and event-like. The French imparfait is different ${ }^{10}$ and characterizes the main eventuality as unbounded, which, in SDRT as in DRT, we characterize as a state. But unlike DRT, we place no special temporal relation introduced by the imparfait. This is crucial, as we claim that it is discourse structure that imposes the temporal relation between the eventuality introduced by the main verb in a clause and the main eventuality of the constituent it is related to. Thus, SDRT explains the difference between the examples (16-a) from Bras and Asher (1994) and (16-b) which is translated from Hinrichs (1986), where the eventuality introduced by the imparfait is either wholly anterior (16-a) or wholly posterior to the eventuality (16-b) introduced by the main verb in the first sentence, by showing how different discourse relations, Explanation (16-a) and Result (16-b), are inferred.

(16) (a) Marie arriva au cinéma en retard. Elle attendait son mari à la maison.

(b) Max éteignit la lumière. Il faisait nuit noire autour de lui.

\footnotetext{
${ }^{10}$ We are here considering the standard meaning of the imparfait, and not, e.g., the cases of repetitive imparfait nor narrative imparfait, although the latter is often triggered by, precisely, LA in IP-Adj position.
} 
So, let us observe how our LAs in IP-Adj position interact with states introduced by the imparfait. Consider the following contrast.

(17) (a) Pendant ce temps les troubles s'accentuèrent. [from the German resistance corpus]

(b) Pendant ce temps les troubles s'accentuaient.

In (17-a) the LA locates the event within the interval anaphorically referred to, which our account predicts very well. On the other hand, in (17-b), most speakers understand the eventuality described by the main verb as INCLUDING the time to which the LA anaphorically refers. How can we account for this reversal in the interpretation of the LA by the tense switch?For (17-b), our semantics predicts that in the topic, we have a state - this information is inherited from the aspectual nature of the verb in the main clause, through the $\pi \nabla P$ constraint - in which there is a substate in which the troubles increase. The property introduced by pendant ce temps 'during this time' tells us that all substates of the state in the topic occur within the temporal interval it anaphorically refers to.

However, because states are unbounded, a general principle (States perdure) allows the inference that the substate introduced by the IP's main verb perdures beyond that interval, thus accounting for the temporal intuitions about the relation between the adverbial and the main eventuality.

(States perdure) $\quad(\varphi(s) \wedge \operatorname{State}(s))>\exists s^{\prime}\left(\operatorname{State}\left(s^{\prime}\right) \wedge \mathrm{s} \subseteq_{\mathrm{t}} \mathrm{s}^{\prime} \wedge\right.$ $\left.\varphi\left(\mathrm{s}^{\prime}\right)\right)$ 
Obviously, such a default extension may be blocked by several mechanisms. Indeed, there are examples in the German resistance corpus that contrast with (17-b) in that the inference that the state holds before and after the complement of pendant does not apply:

(18) Pendant la guerre, la Gestapo bénéficiait de pleins pouvoirs exceptionnels, et put faire régner la terreur sans se préoccuper de conserver les apparences d'un état de droit.

The blocking of the state extension beyond the war in (18) is due to the causal relationship between the war and the exceptional powers granted to the Gestapo.

The extension phenomena at work in (17-b) is also involved in the interaction between imparfait and the LAs $X$ ext-DP (heures/jours/ans...) plus tard, for which it has been proposed that the LA introduced a time (referential reading) at which the state holds, rather than simply applying the order and distance relation between the eventuality and the anaphorical time or event (relational reading) (Aurnague et al., 2001).

(19) Les reptiles furent les premiers animaux à paraître sur la terre. Dix millions d'années plus tard, ils peuplaient tous les continents.

In fact, intuitions about the temporal relation of the LA in the second sentence of (19) to the main verb indicate that the state introduced by the imparfait on the main verb could have started well before the point in time 
situated ten million years after the event described in the first sentence. Our analysis predicts that there is a state in the topic created by the second sentence of (19) that includes a substate in which the reptiles inhabit all the continents and that is ten million years later than the event from the first sentence of (19) that is picked up by the LA. ${ }^{11}$ Once again due to the unbounded nature of states, we can infer at least by default that the substate perdures beyond the temporal limit imposed by the LA, because of the unbounded nature of states. And this can be done without giving up our relational analysis of LAs, contrary to what was suggested in Aurnague et al. (2001).

Thus, for us, intuitions about the temporal relation between the state introduced by the imparfait and an LA in IP-Adj position are a product of the discourse structure we predict such LAs introduce and inferences that speakers naturally perform about the unbounded nature of states.

\section{Spatio-temporal interpretation of locating adverbials}

In Asher et al. (1995), we showed that both temporal and spatial LAs could take what we had called a 'spatio-temporal interpretation' in trajectory

${ }^{11}$ SDRT experts may notice that the anaphora resolution of the pronoun ils requires to modify the standard procedure. The topic constituent is attached to the first clause with the coordinating relation of Result, and the IP constituent is dominated by the topic with the subordinating relation of Elaboration. Using the standard definition of available antecedents in SDRT, such a structure would prevent les reptiles from serving as antecedent for the pronoun. This is only another case to argue for the need, already encountered in other occasions (Vieu and Prévot, 2004), to extend the definition of available antecedents to cover also the referents of the last constituent. The event of the first clause can still serve as an antecedent for the anaphoric LA in the topic constituent without any change. 
contexts, e.g., in narratives describing itineraries. For instance, in the fifth clause $\pi 5$ of example (20), taken from Aurnague et al. (2001), dix minutes plus tard 'ten minutes later' and dix kilomètres plus loin 'ten kilometres further' can be substituted one for the other, with the same spatio-temporal reading: it started thundering at some point after Cordes along the trajectory AND after the time at which the rain became hail. The same phenomenon is involved in $\pi 4$ : à Cordes 'at Cordes' in this context is equivalent to '[Jean] having reached Cordes'.

(20) Jean arriva à la hauteur d'Albi $(\pi 1)$. On ne voyait rien du paysage $(\pi 2)$. Il pleuvait à verse depuis Toulouse $(\pi 3)$. À Cordes, la pluie se transforma en grêle $(\pi 4)$, et, dix minutes plus tard / dix kilomètres plus loin, le tonnerre se mit à gronder $(\pi 5)$.

In our earlier work of 1995, we accounted for the two different interpretations that a LA can take, assuming that the LA's semantic was ambiguous between two readings. But the spatio-temporal interpretation is clearly a pragmatic phenomenon since it arises only in some specific contexts $^{12}$ and can be overridden, so a simple semantic approach is not really appropriate. We therefore give here a modified account of this phenomenon, integrated with our proposal for LAs in IP-Adj position in

\footnotetext{
${ }^{12} \mathrm{We}$ are considering here 'purely' temporal or spatial LAs, and not the few genuinely spatio-temporal LAs, like depuis Toulouse, which mix a temporal preposition and a spatial complement, and for which the spatio-temporal interpretation is the only one available, be they in IP-Adj or VP-Adj position.
} 
general, for, as noted in Aurnague et al. (2001) the spatio-temporal interpretation occurs only with LAs in IP-Adj position.

Our hypothesis is that in a trajectory context, the LA in IP-Adj position triggers the presupposition that the objects involved in the trajectory have continued their movement up to being located themselves by the LA. In SDRT, presuppositions make up separated constituents, attached to the main clause by the relation of Background (Asher and Lascarides, 1998). Therefore, we claim here that the spatio-temporal interpretation amounts to the introduction in the SDRS of yet another simple constituent whose propositional content includes a motion event and its resulting state of being located by the LA, the resulting state being the main eventuality. This constituent is attached to the topic introduced by the LA in IP-Adj position by the relation of Background, a relation that is now considered as being subordinating (Vieu and Prévot, 2004). The semantics of Background is spatio-temporal overlap between the main eventualities of the two constituents (Asher et al., 1995). It thus entails that the main eventuality of the topic introduced by the LA shares at least partially both the spatial and temporal location of the resulting state of the presupposed completion of the trajectory, and as a result, the eventuality of the topic is spatio-temporally located.

[Fig 9 hereabouts] 
Fig. 9 shows the schema of the SDRS for (20), on which $\pi^{\prime}$ is the overall topic (Jean's trip), $\pi^{\prime \prime}$ is the topic introduced by the LA $a$ Cordes, $\pi^{\prime \prime \prime}$ that of the LA dix minutes/kilomètres plus tard, $\pi p 1$ is the presupposition that Jean moved from Albi to Cordes and $\pi p 2$ the presupposition that Jean moved further on along his trajectory after Cordes. ${ }^{13}$

\section{Conclusion}

In this paper, we have proposed a formal account of locating adverbials in IP-Adjunct position which is grounded on principles of compositional semantics and at the same time explains their role at the discourse level, in particular, the frame introducer role described by Charolles (1997).

Our approach is situated in the framework of Segmented Discourse Representation Theory (Asher and Lascarides, 2003) and makes an extensive use of SDRT's notion of discourse topic, as LAs in IP-Adj position are taken to be primarily 'new topic introducers'. The proposal takes into account some complex interactions between LAs, narrative structure and temporal structure that have been observed by Le Draoulec and Péry-Woodley (2003). It also gives a new, more satisfactory, explanation of the spatio-temporal interpretation of LAs that was first described in Asher et al (1995).

\footnotetext{
13 The presupposition of continued motion seems to be supplemented with yet another pragmatic element in some cases. Especially with imparfait sentences in a trajectory context, the IP-adj may implicitly refer to some perception event of the described state by the moving agent. We will address this issue in a following paper.
} 
It is more than likely that other IP-adjuncts also interact with the topical structure of a text. In particular, we conjecture that the contribution of temporal connectives such as puis, alors, aussitôt and soudain to the discourse structure as markers of discourse relations, which has already been studied within the SDRT framework (Bras et al., 2001), or in a more descriptive account (Le Draoulec, 2005; Le Draoulec and Bras, 2004), could be reconsidered and extended taking into account their role of new topic marker.

\section{Authors' addresses}

Laure Vieu,vieu@irit.fr

Myriam Bras, bras@univ-tlse2.fr

Nicholas Asher, nasher@mail.utexas.edu

Michel Aurnague, aurnague@univ-pau.fr

Addresses for correspondence:

Laure Vieu

LOA-ISTC-CNR

via Solteri 38, 38100 Trento, Italy

Myriam Bras

ERSS - Maison de la Recherche, Université Toulouse Le Mirail

5 allées Antonio Machado, 31058 Toulouse Cedex 9, France 


\section{REFERENCES}

Asher, N. (1993). Reference to Abstract Objects in Discourse. Dordrecht: Kluwer.

Asher, N. (2004). Discourse topic. Theoretical Linguistics, 30(2/3): 163203.

Asher, N. and Lascarides, A. (1998). The semantics and pragmatics of presupposition. Journal of Semantics, 15(3): 239-300.

Asher, N. and Lascarides, A. (2003). Logics of Conversation. Cambridge: Cambridge University Press.

Asher, N., Aurnague, M., Bras, M. and Vieu, L. (1995). Spatial, temporal and spatio-temporal locating adverbials in discourse. In: P. Amsili, M. Borillo and L. Vieu (eds), Time, Space and Movement. Meaning and Knowledge in the Sensible World. Workshop Notes of the 5th International Workshop TSM'95, Toulouse, pp. A107-119.

Aurnague, M., Bras, M., Vieu, L. and Asher, N. (2001). The syntax and semantics of locating adverbials. Cahiers de Grammaire, 26: 11-35.

Bonami, O., Godard, D. and Kampers-Manhe, B. (2004). Adverb classification. In: F. Corblin and H. De Swart (eds), Handbook of French Semantics. Standford: CSLI Publications, pp.143-184. 
Borillo, A., Bras, M., Le Draoulec, Vieu, L., Molendijk, A., De Swart, H., Verkuyl, H., Vet, C. and Vetters, C. (2004). Tense, connectives and discourse. In: F. Corblin and H. De Swart (eds), Handbook of French Semantics. Standford: CSLI Publications, pp. 309-348.

Bras, M., Le Draoulec, A. and Vieu L. (2001). French adverbial puis between temporal structure and discourse structure. In: M. Bras and L. Vieu (eds), Semantic and Pragmatic Issues in Discourse and Dialogue: Experimenting with Current Theories. Oxford: Elsevier (CRiSPI), pp. 109-146.

Bras, M. and Asher, N. (1994). Le raisonnement non-monotone dans la construction de la structure temporelle de textes en français. In: Actes de RFIA'94, volume 2. Paris: AFCET, pp. 223-234.

Busquets, J., Vieu, L. and Asher, N. (2001). La SDRT : Une approche de la cohérence du discours dans la tradition de la sémantique dynamique. Verbum, 23(1): 73-101.

Charolles, M. (1997). L'encadrement du discours : univers, champs, domaines et espaces. Cahiers de Recherche Linguistique, 6: 1-73. Nancy: LANDISCO.

Charolles, M., Le Draoulec, A., Péry-Woodley, M.P. and Sarda, L. Temporal and spatial dimensions of discourse organisation, this volume. 
Davidson, D. (1967). The logical form of action sentences. In: N. Rescher (ed.), The logic of Decision and Action. Pittsburgh: The University of Pittsburgh Press, pp. 81-95.

De Swart, H., (1999). Position and Meaning: Time Adverbials in Context. In: P. Bosch and R. van der Sandt (eds), Focus Linguistic, cognitive and computational perspectives. Cambridge: Cambridge University Press, pp. 336-361.

Diesing, M. (1992). Indefinites. Cambridge (MA): MIT Press.

Hinrichs, E. (1986). Temporal anaphora in discourses of English. Linguistics and Philosophy, 9: 63-82.

Johnston, M. (1994). The syntax and the semantics of adverbials adjuncts. Unpublished $\mathrm{PhD}$ dissertation, University of California at Santa Cruz.

Kamp, H. (1981). Evénements, représentations discursives et référence temporelle. Langages, 64: 34-64.

Kamp H. and Rohrer, C. (1983). Tense in Texts. In: R. Bauerle, C. Schwarze and A. von Stechow (eds), Meaning, Use and Interpretation of Language. Berlin: De Gruyter, pp. 250-269.

Kamp, H. and Reyle, U. (1993). From Discourse to Logic. Dordrecht: Kluwer. 
Lascarides, A. and Asher, N. (1993). Temporal Interpretation, Discourse Relations, and Commonsense Entailment. Linguistics and Philosophy, 16(5): 437-493.

Le Draoulec, A. (2005). Connecteurs temporels d'immédiateté : le cas de aussitôt et soudain. Cahiers Chronos, 12 : 19-34.

Le Draoulec, A. and Bras, M. (2004). Rôles de alors temporel dans la structuration du discours. Colloque Chronos'6, Genève.

Le Draoulec, A. and Péry-Woodley, M.P. (2003). Time travel in text: Temporal framing in narratives and non-narratives. In: L. Lagerwerf, W. Spooren and L. Degan (eds), Determination of Information and Tenor in Texts: Multidisciplinary Approaches to Discourse. Amsterdam: Stichting Neerlandistiek VU / Münster: Nodus Publikationen, pp.267275.

McConnell-Ginet, S. (1982). Adverbs and logical form: a linguistically realistic theory. Language, 58(1): 144-184.

McKercher, D.A. (1996). On the Syntax and Semantics of English Adverbials. Unpublished Master of Art Thesis, University of Victoria.

Maienborn, C. (1995). Toward a Compositional Semantics for Locative Modifiers. In: Proceedings from Semantics and Linguistic Theory $V$. Ithaca New York: Cornell University Linguistic Publications, pp. 237254. 
Molinier, C. and Lévrier, F. (2000). Grammaire des adverbes : description des formes en -ment. Genève-Paris: Droz.

Partee, B. and Rooth, M. (1983). Generalized Conjuction and Type Ambituity. In: R. Bauerle, C. Schwarze and A. Von Stechow (eds), Meaning, Use and Interpretation of Language. Berlin: De Gryuter, pp. $361-383$

Txurruka Gómez, I. (1999). Focus in Discourse: Alternative semantics vs SDRT. International Colloquium in Cognitive Science ICSS'99, Donostia.

Txurruka Gómez, I. (2001). Foco y tema: una aproximación discursiva. Bilbao: Universidad del País Vasco.

Vallduví, E. (1992). Information packaging. Garland: New York.

Vieu, L. and Prévot, L. (2004). Background in SDRT. In: TALN-04 Workshop on SDRT, Fès. 


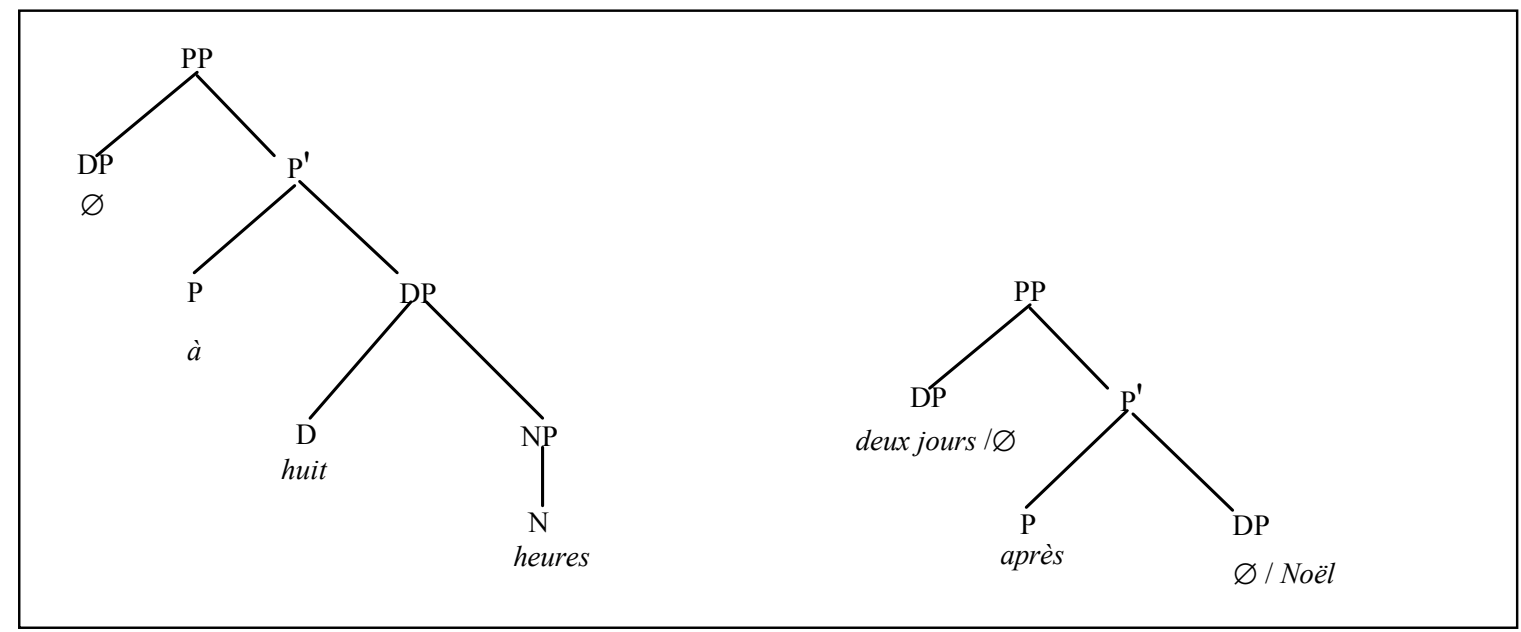

Figure $1:$ Internal syntactic structure of

à huit heures, deux jours après, deux jours après Noël, après Noël, après 


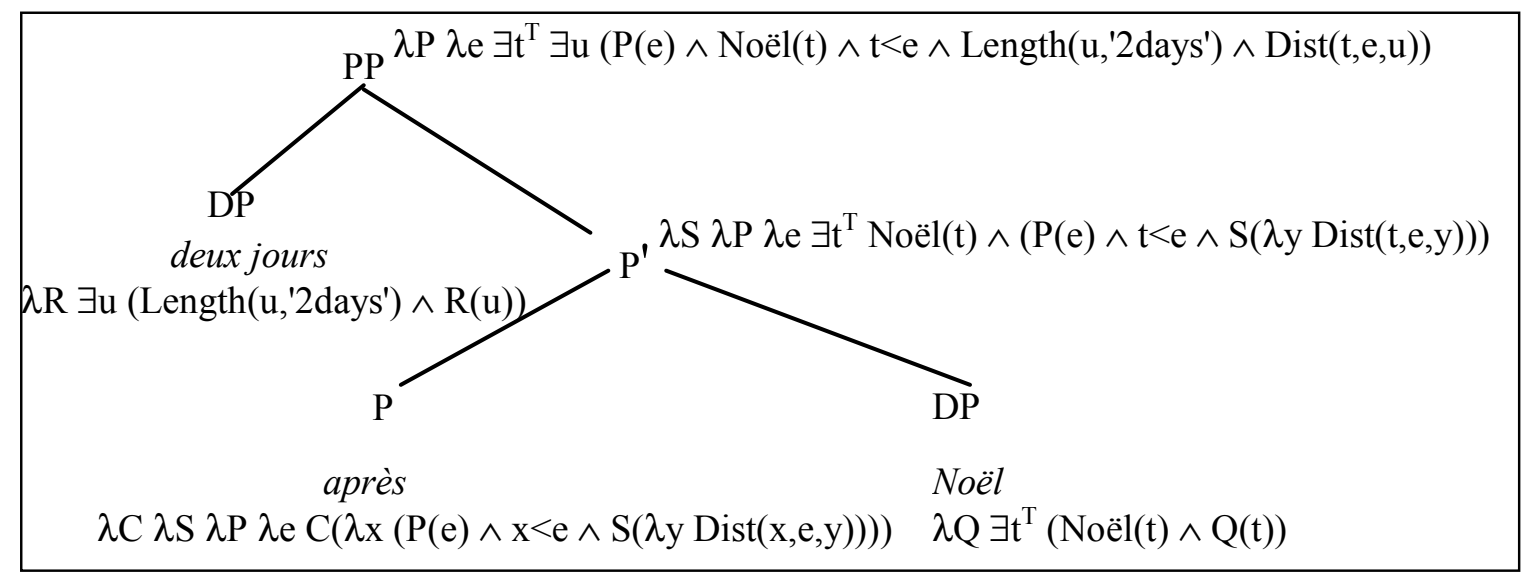

Figure 2 : Compositional calculus of the semantics of deux jours après Noël 


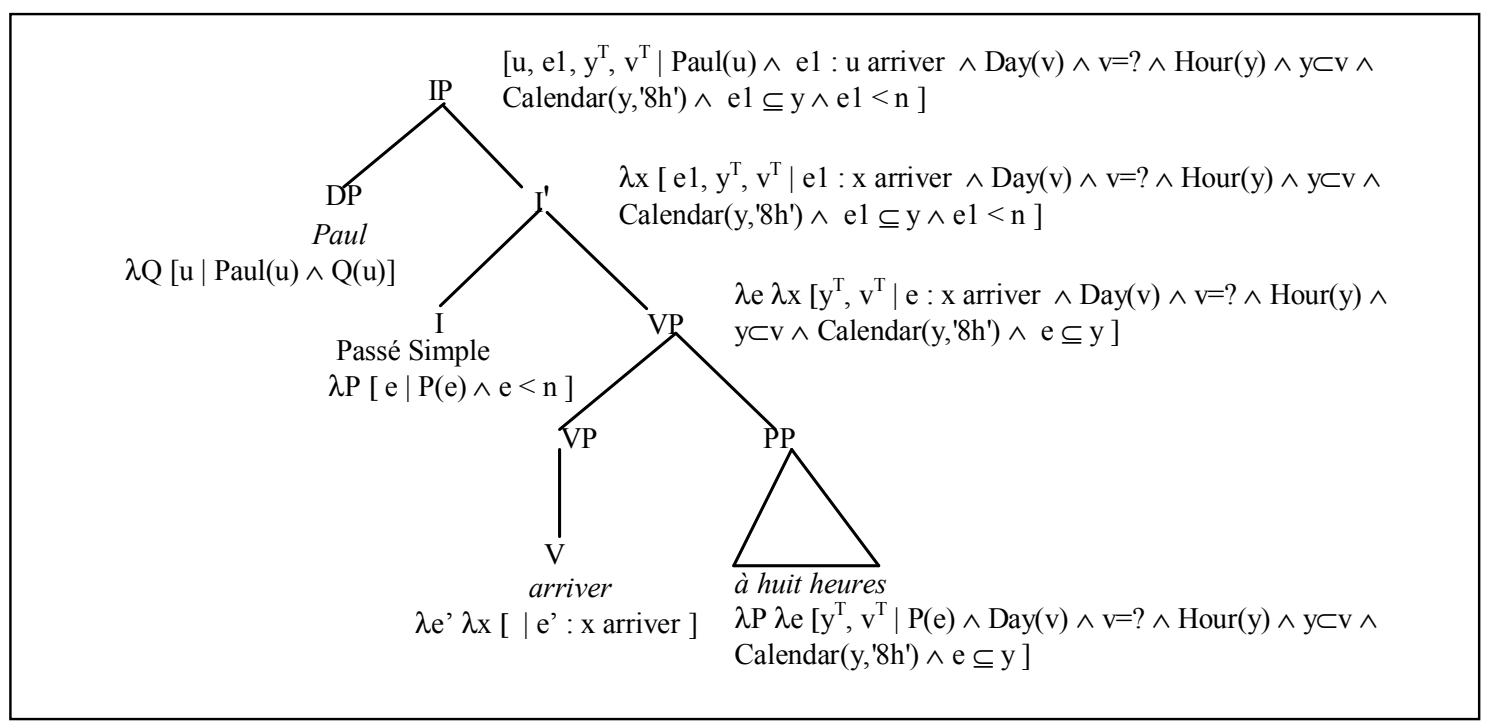

Figure 3 : Compositional semantics of (6) 


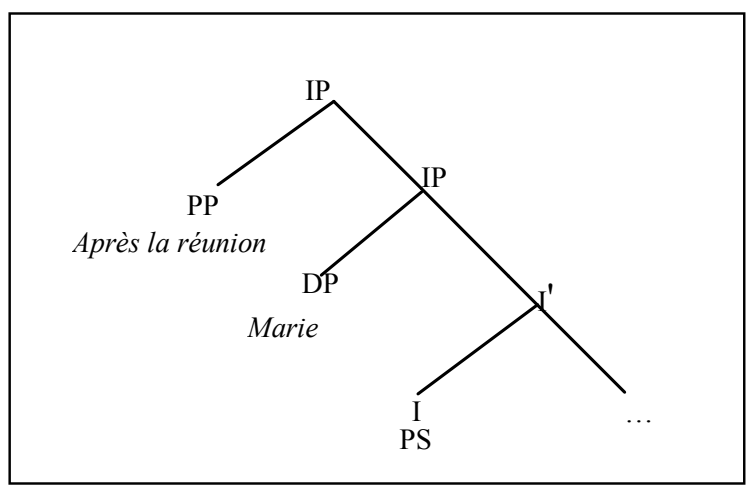

Figure 4: LA in IP-Adj position 
[Hier]

Marie est allée au marché pour acheter des abricots.

Elle a fait une tarte délicieuse et nous nous sommes tous régalés.

Figure 5 : Temporal discourse framing in (8) 


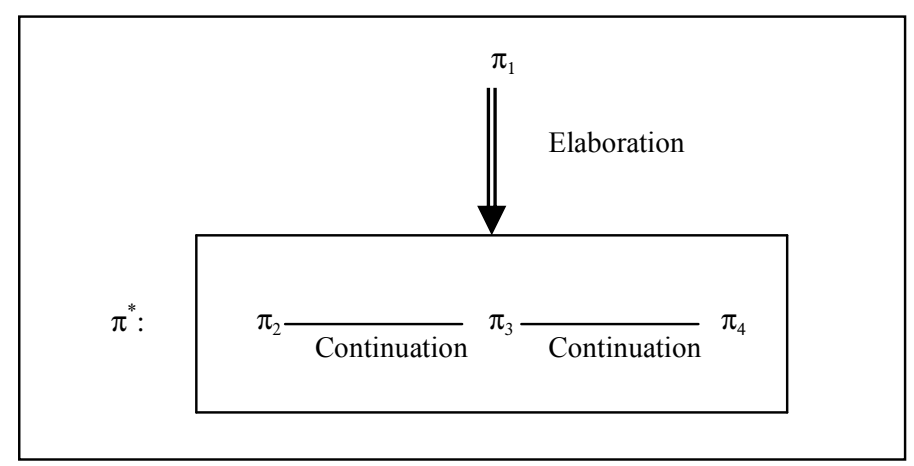

Figure 6: Sketchy SDRS for (9) 


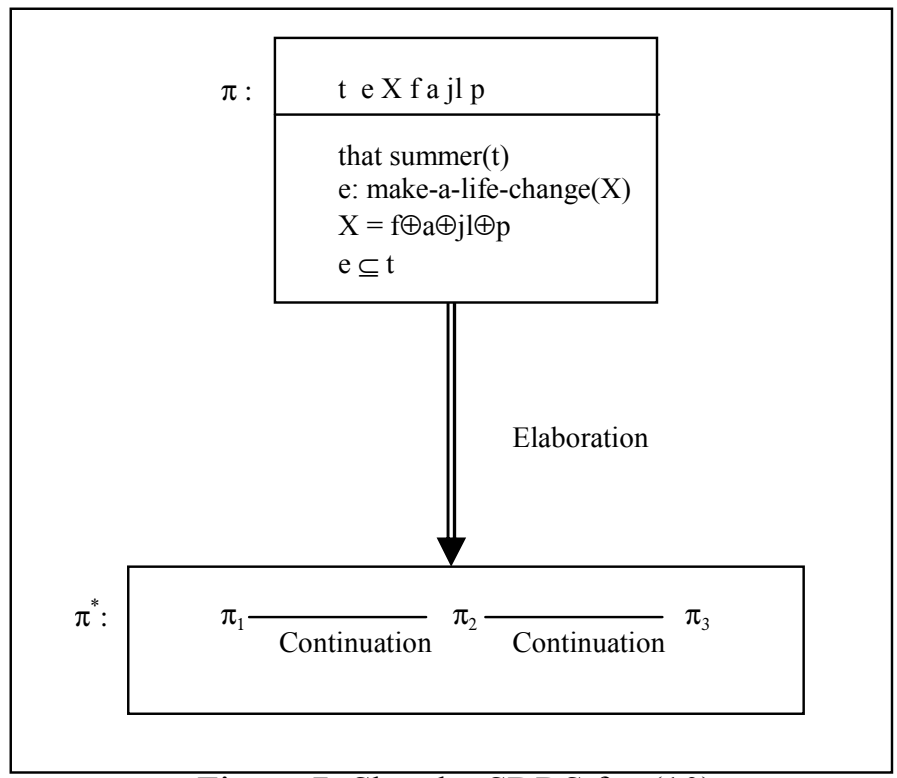

Figure 7: Sketchy SDRS for (10) 


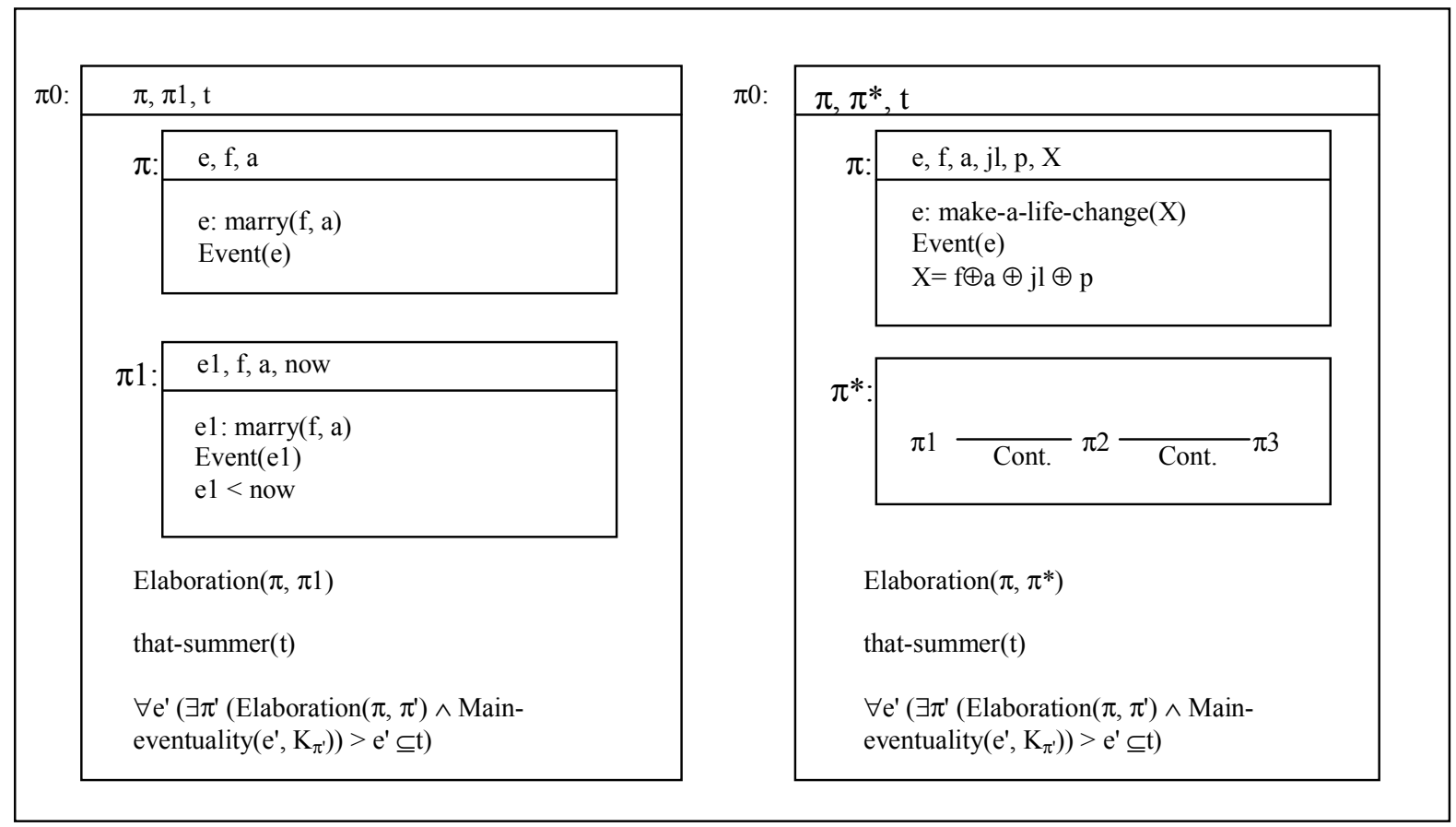

Figure 8.1: First step in building the SDRS

Figure 8.2 : Resulting SDRS

Figure 8: SDRS for example (10) 


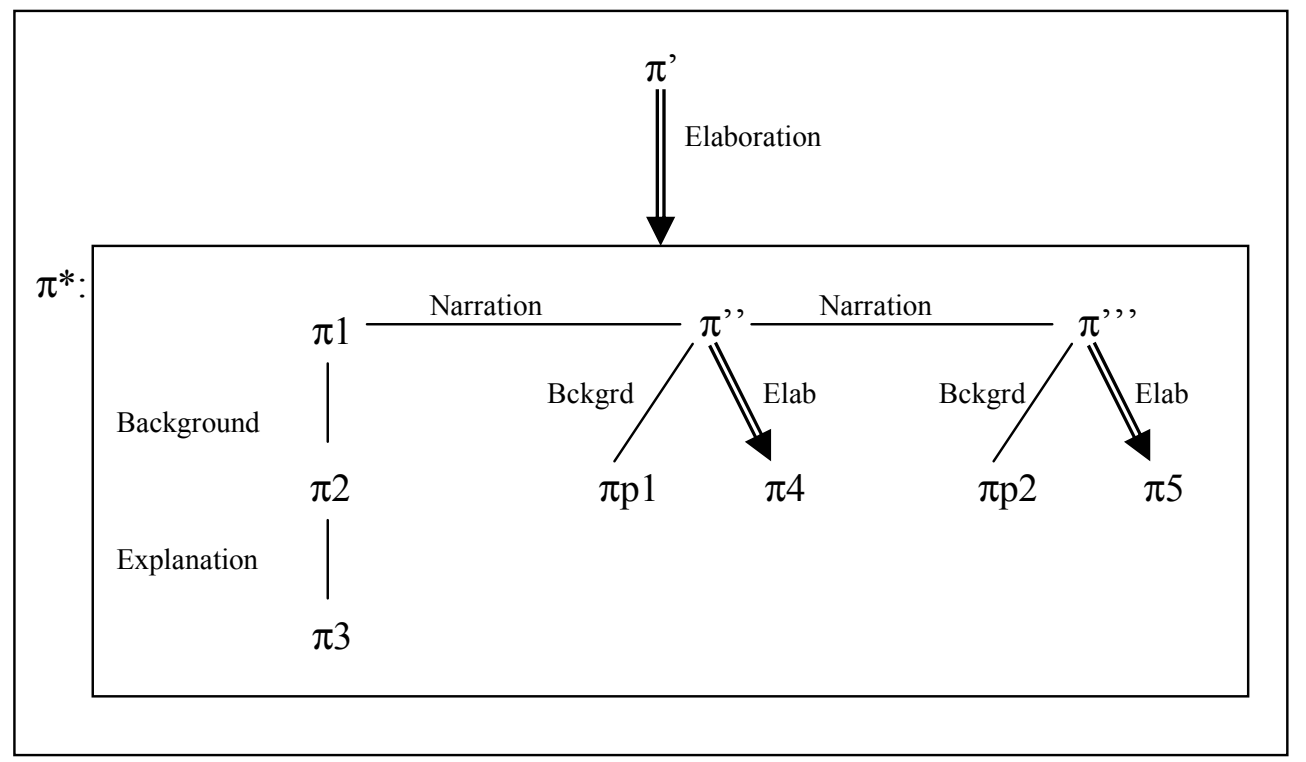

Figure 9: Sketchy SDRS for example (20) 